\title{
PENINGKATAN HASIL BELAJAR MENULIS TEKS LAPORAN HASIL OBSERVASI DENGAN PENDEKATAN INTEGRATIF
}

\author{
Ni Ketut Ambarawati \\ SMA Negeri 2 Sungai Raya \\ Email: Ni Ketut Ambarawati@gmail.com
}

\begin{abstract}
The aim of this research is to describe the improvement in learning outcomes of writing text of observation report on class $X$ students of SMA Negeri 2 Sungai Raya with an integrative approach. This approach is to increase students' learning motivation so that the learning outcomes obtained are better. This type of research used in this research is classroom action research (CAR) which consists of two cycles. The location of the study was at SMA Negeri 2 Sungai Raya. The research subjects were students of class X IPA2 semester in academic year 2019/2020. The application of the integrative approach is carried out through 5 stages: (a) preparation, (b) problem orientation, $(c)$ group assignment, $(d)$ group presentation, and (e) evaluation. Observations were made using instruments in the form of observation sheets of teacher and student activities to record their activities in learning. Based on Cycle I and Cycle II, the application of integrative approaches in learning Indonesian can be implemented well. It can be seen from the observation sheet of the implementation of research and student activities while following the learning process. The student learning outcomes in writing written text of the observation report has increased, seen from the percentage of learning outcomes that increased from students completeness by $38 \%$ in Cycle I to $90 \%$ in Cycle II. It was proven that the application of the integrative approach can improve student learning outcomes.
\end{abstract}

\section{Keywords: Integrative Approach; Learning outcomes; Writing Text of Observation Report}

\section{PENDAHULUAN}

Pembelajaran

bahasa Indonesia mencakup empat keterampilan berbahasa, yaitu menyimak, membaca, berbicara, dan menulis. Keterampilan menyimak dan membaca dikategorikan sebagai keterampilan berbahasa reseptif. Sedangkan keterampilan berbicara dan menulis dikategorikan sebagai keterampilan berbahasa produktif.

Keterampilan menulis merupakan salah satu jenis keterampilan berbahasa yang harus dikuasai peserta didik. Tarigan (2013:3) menyatakan bahwa keterampilan menulis adalah salah satu keterampilan berbahasa yang produktif dan ekspresif yang dipergunakan untuk berkomunikasi secara tidak langsung dan tidak secara tatap muka dengan pihak lain. Keterampilan berbahasa yang produktif melalui kata-kata atau tulisan itu dihasilkan sedangkan terampilan berbahasa ekspresif mampu mengungkapkan gambaran maksud, gagasan dan perasaan penulisnya.

Mata pelajaran Bahasa Indonesia berdasarkan Kurikulum 2013 secara umum bertujuan agar peserta didik mampu mendengarkan, membaca, memirsa, berbicara, dan menulis. Kompetensi dasar dikembangkan berdasarkan tiga hal lingkup materi yang saling berhubungan dan saling mendukung pengembangan kompetensi pengetahuan kebahasaan dan kompetensi keterampilan berbahasa peserta didik. Kompetensi sikap secara terpadu dikembangkan melalui kompetensi pengetahuan kebahasaan dan kompetensi keterampilan berbahasa. Ketiga materi tersebut adalah bahasa, sastra, dan literasi.

Mata pelajaran Bahasa Indonesia 
khususnya Sekolah Menengah Atas (SMA) terdapat berbagai macam kompetensi dasar yang harus dicapai oleh peserta didik, di antaranya: (1) memahami, struktur dan kaidah teks; (2) menginterpretasi makna teks; (3) membandingkan teks; (4) memproduksi teks; (5) menganalisis teks; (6) menyunting teks, (7) mengidentifikasi teks; (8) mengabstraksi teks; (9) mengevaluasi teks; dan (10) mengonversi teks. Pembelajarannya menggunakan teks sebagai basisnya. Khususnya di kelas $\mathrm{X}$ ini peserta didik diajarkan pada berbagai macam teks, seperti laporan hasil observasi, eksposisi, teks anekdot, hikayat, teks negosiasi, debat, teks biografi, dan puisi (Permendikbud 2013 dalam Priyatni, 2014:67).

Setiap teks memiliki struktur teks. Struktur teks membentuk struktur berpikir sehingga di setiap penguasaan jenis teks tertentu, peserta didik akan memiliki kemampuan berpikir sesuai dengan struktur teks yang dikuasainya. Peningkatkan kemampuan menulis peserta didik serta menjadikan peserta didik lebih produktif, Kompetensi Dasar (KD) memproduksi teks merupakan salah satu yang ditekankan oleh kurikulum 2013, (Permendikbud tahun 2016, nomor 24, tentang KI-KD). Hal tersebut tercantum dalam KD 4.2 mengkonstruksikan teks laporan dengan memerhatikan isi dan aspek kebahasaan baik lisan maupun tulis. Berdasarkan KD tersebut peserta didik dituntut untuk mampu memproduksi teks dengan baik dan benar sesuai dengan struktur berpikirnya. Sejalan dengan hal tersebut, arah pembelajaran keterampilan menulis di SMA berdasarkan Kurikulum 2013 lebih dititikberatkan pada tingkat kreativitas dan daya pikir kritis peserta didik dalam mengembangkan ide dan gagasannya sesuai konteks.

Peserta didik dituntut untuk lebih aktif dan kreatif dalam mencari informasi di dapat menuangkannya kedalam tulisan. Pembelajaran Bahasa Indonesia khususnya di kelas X terdapat satu materi teks baru selain teks yang sudah ada, yaitu teks laporan hasil observasi. Menulis teks laporan hasil observasi mempunyai tingkat kesulitan tersendiri, untuk berbagai macam teks yang sudah dikuasai, untuk itu peserta didik harus mampu menguasai berbagai struktur berpikir. Bahkan, satu topik tertentu pun dapat disajikan dalam jenis teks yang berbeda dan tentunya dengan struktur berpikir yang berbeda pula.

Menulis teks laporan hasil observasi yang dibahas pada kurikulum 2013 ini menuntut peserta didik agar mereka tidak hanya dapat memproduksi teks melainkan mereka juga terlibat sendiri untuk melakukan observasi. Hasil observasi yang berupa data dituangkan ke dalam tulisan untuk dapat menginformasikan kepada pembaca tentang hasil pengamatan yang dilakukan mereka, sehingga hasil informasi yang mereka tuliskan bersifat objektif, faktual bukan berupa opini, dan sistematis sesuai dengan struktur yang telah ditetapkan.

Berdasarkan hasil pengamatan di kelas X SMA Negeri 2 Sungai Raya, tampak bahwa dalam proses belajar mengajar terutama dalam KD memproduksi teks masih banyak peserta didik yang mengalami kesulitan. Mereka mangalami kesulitan dalam memproduksi teks atau menulis sesuai dengan struktur berpikir teks dan kaidah kebahasaannya. Selain itu, mereka sulit untuk menuangkan daya $\mathrm{Hal}$ ini sejalan dengan pendapat bahwa pembelajaran menulis menyiksakan sejumlah masalah yang serius. Salah satu masalah serius tersebut adalah rendahnya kemampuan peserta didik dalam menulis Abidin (2013:190).

Pendekatan pembelajaran integratif dipilih dalam penelitian ini kerena pembelajaran bahasa mencakup aspek mendengarkan, berbicara, membaca, dan menulis yang dilakukan secara terintegrasi. Misalanya, melalui kegiatan pengajaran membaca, pemahaman tentang ejaan, tanda baca, kosakata, kalimat, makna, dan penanda hubungan kewacaan diolah secara serentak. Pengalaman dan pengetahuan yang diperoleh setelah membaca juga berperan dalam mengembangkan kemampuan menulis dan bermanfaat melakukan kegiatan berbicara, baik secara formal maupun informal (Sani, 2016: 265).

Pada teks laporan hasil observasi peserta didik tidak hanya mendengar (audio) 
penjelasan dari guru dan penjelasan dari narasumber tetapi juga terjun langsung ke lapangan untuk mengamati (visual) dan mencari data-data yang diperlukan. Kemudian peserta didik dapat mengolah data tersebut melalui nalarnya sehingga dari proses bernalarnya mereka tuangkan menjadi sebuah tulisan yang bersifat informatif, objektif, faktual bukan berupa opini, dan sistematis sesuai dengan struktur sehingga dalam pembelajaran memproduksi teks laporan hasil observasi dapat berjalan menyenangkan, menarik, dan hasil yang didapat akan maksimal. Selain itu juga Pendekatan pembelajaran integratif sangat relevan dengan mengamati, menanya, menalar, mencoba, mengomunikasikan (5M) yang terdapat di kegiatan inti kurikulum 2013.

Kelebihan Pendekatan pembelajaran integratif untuk materi teks hasil observasi bahwa Pendekatan pembelajaran tersebut siswa dituntun untuk berpikir kritis dengan menggunakan intelektualnya dalam mengolah data serta siswa dapat menggunakan seluruh panca indera mereka dalam membuat teks sehingga menambah pengalaman dan wawasannya mengenai informasi yang akan ia sampaikan melalui teks tertulis dan Pendekatan pembelajaran ini sangat cocok diterapkan dalam teks laporan hasil observasi.

Pada prinsipnya, kegiatan belajar mengajar adalah suatu proses transformasi ilmu pengetahuan dan merupakan proses komunikasi. Proses transformasi berbagai pengetahuan tersebut harus diciptakan atau diwujudkan melalui kegiatan penyampaian dan tukar menukar informasi atau pesan, baik oleh guru dan peserta didik. Adapun yang dimaksud dengan belajar adalah perubahan tingkah laku yang relatif menetap sebagai hasil dari pengalaman (Thompson, 2004).

Menurut Gagne dalam Purwanto (2004), belajar terjadi apabila suatu situasi stimulasi bersama dengan isi ingatan mempengaruhi siswa sedemikian rupa sehingga perbuatannya (performance-nya) berubah dari waktu sebelum ia mengalami situasi itu ke waktu sesudah mengalami situasi tersebut. Jadi suatu pembelajaran dikatakan terjadi atau berhasil apabila stimulus (rangsangan) dan isi pembelajaran mampu mempengaruhi dan mengubah performance seorang peserta didik dari waktu sebelum ia memperoleh pengajaran dengan setelah proses pengajaran berlangsung.

Sudjana (2004) menjelaskan Belajar adalah suatu proses yang ditandai adanya perubahan pada diri seseorang. Perubahan yang terjadi pada individu merupakan perubahan bentuk seperti berubahnya pemahaman, pengetahuan, sikap, tingkah laku, keterampilan, kecakapan, serta keinginan menuju kearah yang lebih baik. Dalam pengertian tersebut tahapan perubahan dapat diartikan sepadan dengan proses. Jadi proses belajar adalah tahapan perubahan perilaku kognitif, afektif dan psikomotor yang terjadi dalam diri siswa. Perubahan tersebut bersifat positif dalam arti berorientasi ke arah yang lebih maju dari pada keadaan sebelumnya. Dalam uraian tersebut digambarkan bahwa belajar adalah aktifitas yang berproses menuju pada satu perubahan dan terjadi melalui tahapan-tahapan tertentu.

Berdasarkan definisi-definisi di atas, dapat disimpulkan bahwa belajar adalah proses perubahan tingkah laku yang diwujudkan dalam bentuk pengetahuan, pemahaman, keterampilan dan sikap berdasarkan pengalaman pribadi (individu), maupun orang lain. Dalam proses pembelajaran kegiatan belajar mengajar, perubahan terhadap aspekaspek intelektual, emosional atau sikap (keterampilan) akan dapat terlihat dalam bentuk hasil belajar. Ini berdasarkan pada respon yang diberikan mahasiswa terhadap stimulus (rangsangan) yang diberikan guru. Baik stimulus tersebut berupa jawaban berbentuk lisan, tulisan, tes ataupun pelaksanaan tugas-tugas.

Winkel (2007) menyatakan hasil belajar adalah setiap macam kegiatan belajar menghasilkan perubahan yang khas yaitu, belajar. Hasil belajar tampak dalam suatu prestasi yang diberikan siswa, misalnya menyebutkan huruf dalam abjad secara berurutan. Hasil belajar merupakan kemampuan, keterampilan, dan sikap seseorang dalam menyelesaikan suatu hal. Hasil suatu pembelajaran (kemampuan, keterampilan, dan sikap) dapat terwujud jika 
pembelajaran (kegiatan belajar mengajar) terjadi (Arifin, 2000). Baik individu ataupun tim, menginginkan suatu pekerjaan dilakukan secara baik dan benar agar memeperoleh hasil yang baik dari pekerjaan tersebut. Keberhasilan ini akan tampak dari pemahaman, pengetahuan atau keterampilan yang dimiliki oleh individu ataupun tim.

Terkait dengan hasil belajar, Djamarah (2007) menyatakan hasil belajar adalah prestasi dari suatu kegiatan yang telah dikerjakan, diciptakan, baik secara individu maupun tim. Menurut Bloom dan ditulis kembali oleh Sudjana (2001), secara garis besar membagi hasil belajar menjadi tiga ranah, yaitu : 1)Ranah kognitif berkenaan dengan hasil belajar intelektual yang terdiri dari enam aplikasi, analisis, sintesis, dan evaluasi. 2)Ranah afektif berkenaan dengan sikap yang terdiri dari lima aspek yaitu penerimaan, jawaban, penilaian, organisasi, dan internalisasi. 3)Ranah Psikomotorik berkenaan dengan hasil belajar berupa keterampilan dan kemampuan bertindak.

Menulis merupakan keterampilan yang lebih sulit dibandingkan tiga keterampilan bahasa yang lain, yaitu menyimak (listening competence),membaca (reading competence), berbicara (speaking competence). Menulis juga merupakan kegiatan yang dilakukan seseorang untuk menghasilkan tulisan, tetapi juga mengungkapkan gagasan. Hal ini sesuai dengan apa yang disampaikan Nurrudin (2007: 4) bahwa menulis adalah segenap rangkaian kegiatan seseorang dalam rangka mengungkapkan gagasan dan menyampaikannya melalui bahasa tulis kepada orang lain agar mudah dipahami. Senada dengan pendapat sebelumnya,

Imron Rosidi (2009:2) mengemukakan menulis merupakan sebuah kegiatan menuangkan pikiran, gagasan, dan perasaan seseorang yang diungkapkan dalam bahasa tulis. Menulis merupakan kegiatan untuk menyatakan pikiran dan perasaan dalam bentuk tulisan yang diharapkan dapat dipahami oleh pembaca dan berfungsi sebagai alat komunikasi secara tidak langsung. Murray (dalam Kristiantari, 2011:99) berpendapat bahwa: 1) menulis itu berpikir; 2) menulis merupakan proses; 3) menulis merupakan interaksi global dan khusus; dan 4) tidak hanya satu cara dalam menulis

Menurut Setiarini dan Artini (2013:46), teks LHO adalah sebuah teks yang menghadirkan informasi tentang suatu hal secara apa adanya. Teks ini merupakan hasil dari observasi dan analisis secara sistematis. Senada dengan pendapat di atas, Kosasih (2013: 43) menyatakan bahwa teks LHO merupakan teks yang mengemukakan faktafakta yang diperoleh melalui pengamatan. Kegiatan mengamati yang dilakukan terhadap suatu objek dengan maksud memahami pengetahuan dari sebuah fenomena berdasarkan pengetahuan dan gagasanuntuk mendapatkan informasi- informasi yang dibutuhkan dalam melakukan suatu penelitian. Dengan adanya teks LHO, pembaca memperoleh sejumlah pengetahuan ataupun wawasan, bukan hasil imajinasi.

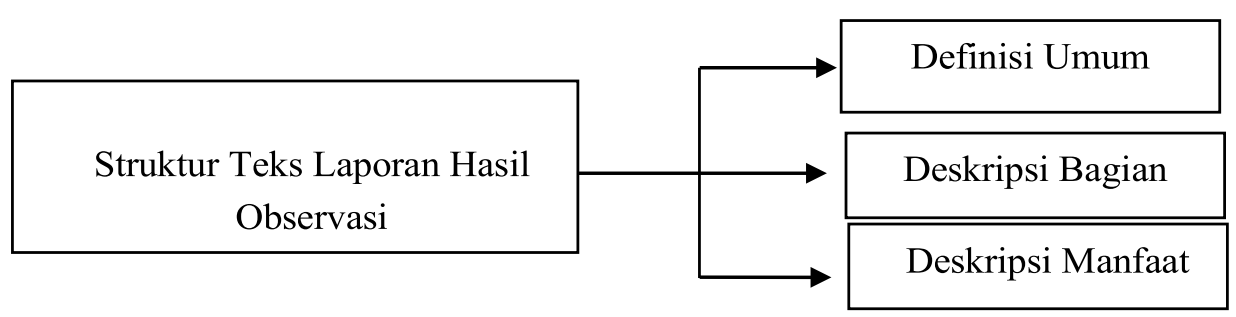

\section{Bagan 1: Struktur Teks Laporan Hasil Observasi}

Berdasarkan pengertian di atas dapat disimpulkan bahwa struktur teks laporan hasil observasi terdiri atas tiga bagian, yaitu definisi umum, deskripsi bagian dan deskripsi manfaat: (1) Definisi umum adalah pernyataan yang memberitahu pembaca tentang apa yang akan dibahas teks atau jabaran deskripsi secara umum terhadap 
objek yang akan ditulis; (2) Deskripsi bagian adalah penjabaran informasi umum, meliputi bagian-bagian dan karakteristik dari informasi umum; (3) Deskripsi manfaat merupakan bagian dari penutup dari teks laporan hasil observasi. Pada bagian ini dijabarkan manfaat atau kegunaan suatu objek.

Pembelajaran bahasa mencakup aspek mendengarkan, berbicara, membaca, dan menulis yang dilakukan secara terintegrasi. Misalanya, melalui kegiatan pengajaran membaca, pemahaman tentang ejaan, tanda baca, kosakata, kalimat, makna, dan penanda hubungan kewacaan diolah secara serentak. Pengalaman dan pengetahuan yang diperoleh setelah membaca juga berperan dalam mengembangkan kemampuan menulis dan bermanfaat melakukan kegiatan berbicara, baik secara formal maupun informal (Sani, 2016: 265).

Pendekatan pembelajaran ini menggunakan pendekatan antar mata pelajaran yang dipadukan. Beberapa mata pelajaran dicari konsep, sikap, dan ketrampilan yang tumpang tindih dipadukan menjadi satu. Kegiatan guru pertama menyeleksi konsep, nilai-nilai dan ketrampilan yang memiliki keterkaitan erat satu sama lain dari berbagai mata pelajaran. Keuntungan medel pembelajaran ini bagi peserta didik adalah lebih mudah mengaitkan materi pembelajaran dari berbagai mata pelajaran. Pendekatan inilah yang dikembangkan sebagai pembelajaran terpadu di kurikulum 2013. Jalil (2006: 51) dalam jurnalnya mengemukakan bahwa, Pendekatan pembelajaran integratif menggunakan pendekatan antar mata pelajaran yang dipadukan. Beberapa mata pelajaran dicari konsep, sikap, dan ketrampilan yang tumpang tindih dipadukan menjadi satu. Kegiatan guru pertama menyeleksi konsep, nilai-nilai dan ketrampilan yang memiliki keterkaitan erat satu sama lain dari berbagai mata pelajaran. Keuntungan pendekatan pembelajaran ini bagi peserta didik adalah lebih mudah mengaitkan materi pembelajaran dari berbagai mata pelajaran.Juanda (2006:27) mengemukakan bahwa, Pendekatan integratif membuat proses belajar mengajar menjadi relevan dan kontekstual sehingga berarti bagi siswa. Menurut riset otak, fungsi otak akan optimal apabila seseorang mempelajari sesuatu yang bermakna baginya, serta akan menarik minatnya. Dikatakan bermakna karena dalam Pendekatan integratif lebih menekankan keterlibatan siswa dalam belajar. Siswa dibuat secara aktif terlibat dalam proses pembelajaran dan siswa akan memahami konsep-konsep atau aspekaspek keterampilan berbahasa yang dipelajarinya.

Terdapat tujuh unsur kebahasaan yang dibutuhkan dalam menulis teks laporan hasil observasi. Ketujuh unsur kebahasaan tersebut, yaitu (1) rujukan kata; (2) kelompok kata; (3) kata berimbuhan; (4) deskripsi; (5) konjungsi; (6) definisi; dan (7) kebakuan kata (Kemendikbud 2013:11).

Kemendikbud (2013) menetapkan halhal yang perlu diperhatikan dalam penilaian teks laporan hasil observasi dibagi menjadi lima, yaitu (1) isi, (2) organisasi, (3) kosakata, (4) penggunaan bahasa, dan (5) mekanik. Isi berkaitan dengan penguasaan dan pengembangan topik tulisan. Organisasi berkaitan dengan struktur teks laporan hasil observasi dan kaidah kebahasaan. Kosakata berkaitan dengan penguasaan kata, diksi, dan keefektifannya. Penggunaan bahasa berkaitan dengan penguasaan kata, diksi, dan keefektifannya. Penggunaan bahasa berkaitan dengan fungsi/urutan kata, konstruksinya, dan makna dalam kalimat-kalimatnya. Sementara itu, mekanik berkaitan dengan aturan penelitian dan Pedoman Umum Ejaan Bahasa Indonesia

\section{METODE PENELITIAN}

SMA Negeri 2 Sungai Raya merupakan salah satu Sekolah Menengah Atas Negeri yang berlokasi di Jalan Raya Desa Kapur Gg. Pendidikan Kecamatan Sungai Raya Kabupaten Kubu Raya. Sekolah ini menanamkan Pendidikan Karakter pada peserta didiknya. Lokasi ini dipilih karena penulis bekerja sebagai pengajar mata pelajaran bahasa Indonesia di sekolah tersebut 
sehingga lebih mudah dan mengenal karakteristik lingkungan sekolah yang diteliti. Sekolah ini juga memiliki lahan yang luas yang juga biasa ditanami sayur-sayuran organik. Penelitian ini dilaksanakan pada mata pelajaran Bahasa Indonesia materi teks laporan hasil observasi (LHO). Penelitian ini dilaksanakan pada 5-7 Agustus 2019.

Penelitian ini dilaksanakan di Kelas X IPA 2 SMA Negeri 2 Sungai Raya pada Semester I (ganjil) Tahun Pelajaran 2019/2020. Jumlah peserta didik di kelas ini ada 31 yang terdiri atas 15 peserta didik lakilaki dan 16 peserta didik perempuan. Karakteristik peserta didik Kelas X IPA 2 secara kemampuan merupakan kelas yang heterogen.

Untuk memperoleh data yang akurat, peneliti menempuh beberapa cara dalam mengumpulkan data penelitian. Beberapa cara tersebut di antaranya adalah sebagai berikut. Pengamatan Partisipatif. Cara ini digunakan peneliti agar data yang diinginkan dapat diperoleh sama dengan apa yang dimaksudkan oleh peneliti. Pengamatan partisipatif maksudnya adalah peneliti terlibat secara langsung dan bersifat aktif dalam turut serta mengumpulkan data yang diinginkan. Peneliti kadang- kadang juga mengarahkan objek yang diteliti untuk melaksanakan tindakan. Hal ini dilakukan agar objek penelitian yaitu kelas dapat mengarah pada data yang ingin diperoleh oleh peneliti. Menurut Arikunto (2008) sebuah kelas dapat dilihat sebagai satu kesatuan unsur yang bersangkut paut dan bekerja menuju tujuan tertentu. Komponenkomponen dari sebuah kelas adalah: (a) peserta didik itu sendiri, (b) guru yang sedang mengajar, (3) materi pembelajaran, (4) peralatan yang digunakan, (5) hasil pembelajaran, (6) lingkungan pembelajaran, dan (7) pengelolaan/pengaturan yang dilakukan oleh kepala sekolah, baik yang sedang berlangsung maupun tidak. Dengan demikian, objek amatan dalam penelitian tindakan kelas tidak harus selalu ketika proses pembelajaran sedang berlangsung, karena kelas bukan ruangan, tetapi sekelompok siswa; Interview atau Wawancara. Cara atau Pendekatan ini sering disebut dengan wawancara. Pada dasarnya Pendekatan ini merupakan suatu teknik pengumpulan data yang dilakukan dengan cara tanya jawab antara guru dengan guru atau antara guru dengan peserta didik; Dokumentasi. Data produk yaitu berupa karya tulisan berbentuk karangan hasil pembelajaran yang dibuat oleh peserta didik. Berdasarkan data ini dapat diketahui apakah pembelajaran menulis LHO berdasarkan pengalaman tergolong efektif ataukah sebaliknya; Catatan Lapangan. Catatan lapangan merupakan teknik pengumpulan data yang paling praktis dan mudah dilaksanakan kapan saja dan dimana saja. Pencatatan ini dilakukan untuk mencatat kejadian-kejadian sewaktu pembelajaran. Halhal yang dicatat mengacu pada deskripsi guru dan peserta didik yang diteliti.;Tes hasil belajar (Pretest dan Postest). Tes hasil belajar digunakan untuk mengumpulkan data hasil belajar siswa saat mengikuti pembelajaran sebelum dan sesudah menggunakan menulis teks laporan hasil observasi dengan pembelajaran integratif. Tes adalah alat atau prosedur yang digunakan untuk mengetahui atau mengukur sesuatu dengan aturan-aturan yang sudah ditentukan. Instrumen yang digunakan berupa butir-butir soal esai; Prosedur Penelitian. Untuk memperoleh hasil yang optimal, peneliti menggunakan beberapa langkah yang ditempuh. Langkahlangkah yang meliputi perencanaan, tindakan, observasi, dan refleksi tersebut dapat dirinci sebagai berikut: Perencanaan, Tindakan meliputi tindakan I, (Kegiatan Pendahuluan, Kegiatan Inti, Kegiatan Penutup) dan Tindakan II meliputi Kegiatan Pendahuluan, Kegiatan Inti, Kegiatan Penutup

\section{HASIL DAN PEMBAHASAN PENELITIAN \\ Siklus I}

1) Tahap Perencanaan

Pelaksanaan kegiatan pada siklus I dirancang sebanyak 1 kali pertemuan $(2 \times 45$ menit), dalam hal ini yang dipersiapkan penulis adalah sebagai berikut ini:

a. Menentukan materi pokok yaitu menulis teks LHO. 
b. Menentukan Kompetensi Dasar (KD), Indikator Pencapaian Kompetensi (IPK) serta tujuan pembelajaran mata pelajaran Bahasa Indonesia materi pokok yaitu menulis teks LHO.

c. Membuat Rancangan Pelaksanaan Pembelajaran (RPP) sesuai materi yang akan diajarkan, yaitu materi pokok menulis teks LHO pada mata pelajaran Bahasa Indonesia yang terdiri dari kegiatan awal, kegiatan inti, dan kegiatan akhir.

d. Membuat instrumen penilaian peserta didik yang meliputi penilaian sikap, pengetahuan, dan penilaian kepeterampilan.Menulis lembarpenilaian individu.

Siklus I dirancang dengan menggunakan indikator sebagai berikut: (a) menganalis teks laporan hasil observasi, dan (b) menganalisis kebahasaan teks laporan hasil observasi. Pertemuan siklus I dirancang untuk melakukan pembelajaran dengan menggunakan pendekatan pembelajaran integratif dengan keranjang bahasa dan diskusi kelompok tentang klasifikasi bahasa. Kemudian dilanjutkan berdiskusi tentang kesalahan berbahasa dalam penulisan teks LHO. Selain itu, guru juga menyiapkan lembar penilaian proses untuk merekam aktivitas dan keaktifan peserta didik selama proses pembelajaran berlangsung

\section{2) Tahap Pelaksanaan}

Pelaksanaan proses pembelajaran untuk siklus I dilaksanakan sebanyak 1 kali pertemuan yang dilaksanakan pada hari Senin, 5 Agustus 2019 jam pelajaran ke 1-2 pada pukul 07.45 sampai dengan pukul 09.15 WIB. Peneliti memasuki kelas didampingi 1 orang observer dari teman sejawat yang bertindak sebagai pengamat selama penelitian tindakan kelas berlangsung. Alokasi waktu dalam 1 jam pelajaran adalah 45 menit, sehingga total. Pelaksanaan pembelajaran pada Siklus I adalah $2 \times 45$ menit (90 menit). Pengamatan dilaksanakan peneliti dan dibantu 1 orang observer, yaitu teman sejawat guru Bahasa Indonesia SMA Negeri 2 Sungai Raya. Penerapan pendekatan pembelajaran integratif dilaksanakan melalui 5 tahapan yaitu: (a) persiapan, (b) orientasi masalah, (c) penugasan kelompok, (d) presentasi kelompok, dan (e) evaluasi. Pengamatan dilakukan dengan menggunakan instrumen berupa lembar observasi aktivitas guru dan peserta didik untuk merekam kegiatan mereka dalam pembelajaran. Sebelum memulai pembelajaran, guru mengajak peserta didik berdoa sebagai rasa syukur karena mendapat kesempatan mempelajari Teks LHO. Dari sini peserta didik diharapkan termotivasi untuk memiliki semangat dalam mengikuti pembelajaran. Selanjutnya, guru mengawali kegiatandenganapersepsi, yaitu menanyakan materi yang telah dipelajari pada pertemuan sebelumnya. Selain itu, guru menjelaskan tujuan pembelajaran yang akan dicapai, cakupan materi, dan penjelasan uraian kegiatan pembelajaran.

Hal ini dilakukan agar peserta didik mempunyai kesiapan dalam mengikuti kegiatan pembelajaran yang akan dilakukan.

Tahap yang kedua dari proses pembelajaran dengan penerapan pendekatan pembelajaran integratif adalah tahap orientasi masalah. Peserta didik diarahkan untuk menyimak video 1 tentang unsur kebahasaan (kata, frasa, klausa, dan kalimat) dan kritis terhadap penggunaan bahasa dalam teks LHO: (a) setiap kelompok diarahkan untuk menempati posisi yang telah ditetapkan; (b) kelompok berbaris ke belakang di samping meja kelompoknya, di meja ini sudah terdapat empat keranjang yaitu keranjang kata, keranjang frasa, keranjang klausa, dan keranjang kalimat; (c) peserta didik berlari ke meja tengah untuk mengambil kertas yang terdapat dalam 'bank bahasa', secara acak; (d) peserta didik berlari ke meja kelompoknya dan memasukkan kertas yang telah dipilih ke dalam keranjang sesuai dengan kriterianya (kartu berisi kata dimasukkan ke keranjang kata, kartu frasa dimasukkan ke keranjang frasa, kartu klausa dimasukkan ke keranjang klausa, kartu kalimat dimasukkan ke keranjang kalimat); (e) peserta didik kedua dan seterusnya melakukan hal yang sama secara marathon sampai waktu yang ditentukan berakhir.

Tahapan selanjutnya adalah penugasan individu. Tahapan ini merupakan tahapan paling 
penting dalam pembelajaran dengan penerapan pendekatan pembelajaran integratif. Kegiatan ini dimulai dengan guru memberikan lembar kerja yang berisi klasifikasi jenis kata, jenis frasa, jenis klausa, dan jenis kalimat dan teks LHO. Setiap peserta didik dalam kelompok berdiskusi tentang subklasifikasi unsur bahasa dan menyimpulkan ciri- ciri masing-masing unsur kebahasaan. Berdasarkan ciri-ciri tersebut, peserta didik diminta mencari 4 kesalahan berbahasa dalam teks LHO dan membenahi kesalahan berbahasa tersebut. Setelahmenyelesaikantugasnya, peserta didik secara bergantian mempresentasikan hasil diskusi yang terwujud dalam lembar kerjanya. Peserta didik dari kelompok lain memberikan pertanyaan, sanggahan, maupun tambahan informasi dari presentasi tersebut. Akhir kegiatan dari kegiatan inti adalah peserta didik dan guru mengevaluasi hasil penyelidikan peserta didik dengan diskusi klasikal untuk memberikan masukan dan menyimpulkan ketepatan unsur kebahasaan teks LHO yang telah dikerjakan setiap kelompok. Kegiatan ini dilakukan dengan tujuan untuk mengetahui keberhasilan kegiatan pembelajaran oleh guru sekaligus mengukur tingkat keberhasilan pendekatan pembelajaran integratif dengan penugasan kelompok yang diterapkan oleh peneliti.

\section{3) Hasil Observasi}

Kegiatan pembelajaran Bahasa Indonesia materi menulis teks LHO Siklus I dengan mengunakan pendekatan pembelajaran integratif melalui metode tanya-jawab, diskusi kelompok, diskusi klasikal, serta penugasan kelompok, memperoleh hasil yang kurang baik karena belum memenuhi kriteria ketuntasan minimal (KKM) klasikal lebih dari $68 \%$. Rincian persentase nilai tindakan Siklus I adalah sebagai berikut:

Tabel 1. Persentase Nilai Tindakan Siklus I

\begin{tabular}{lcc}
\hline \multicolumn{1}{c}{ Ketuntasan Hasil Belajar Peserta didik } & Jumlah & $\begin{array}{c}\text { Persentase } \\
\mathbf{\%}\end{array}$ \\
\hline $\begin{array}{l}\text { Jumlah peserta didik yang tuntas nilai lebih besar sama } \\
\text { dengan 68 }\end{array}$ & 10 & $32 \%$ \\
\hline $\begin{array}{l}\text { Jumlah peserta didik yang belum tuntas nilai kurang } \\
\text { dari 68 }\end{array}$ & 21 & $68 \%$ \\
\hline Jumlah peserta didik & 31 & \\
\hline
\end{tabular}

Dari Tabel 1 di atas dapat dijelaskan bahwa persentase kelulusan pada Siklus I ini masih kurang baik. Terdapat $32 \%$ peserta didik yang mendapat nilai lebih besar sama dengan 68 yaitu, sebanyak 10 peserta didik. Diperoleh $68 \%$ peserta didik yang mendapat nilai kurang dari 68 yaitu, sebanyak 21 peserta didik. Artinya nilai tersebut belum memenuhi rata-rata kelas, sehingga peneliti berkeinginan untuk terus meningkatkan hasil belajar peserta didik secara keseluruhan pada siklus II

\section{4) Refleksi}

Berdasarkan hasil observasi dan analisis pada siklus I, maka peneliti masih ingin melanjutkan penelitian tindakan kelas ini, karena hasil yang diperoleh cukup maksimal. Peningkatan peserta didik baik dalam proses maupun hasil belajar dapat dilihat pada hasil analisis lembar observasi peserta didik dan hasil tes akhir siklus yang peneliti lakukan. Analisis hasil tes penelitian di atas menyatakan bahwa, terdapat 21 peserta didik yang belum tuntas. Hal ini disebabkan peserta didik masih kurang memahami materi yang disampaikan oleh peneliti. Oleh karena itu, kegiatan pembelajaran selanjutnya akan menggunakan pendekatan integratif dengan metode penugasan individu. Penerapan pendekatan integratif dengan metode penugasan individu pada proses pembelajaran diharapkan akan dapat meningkatkan ketuntasan hasil belajar peserta didik dalam menulis teks LHO pada kegiatan pembelajaran Siklus II 


\section{Siklus II}

\section{1) Tahap Perencanaan}

Pelaksanaan kegiatan pada siklus II dirancang sebanyak 1 kali pertemuan $(4 \times 45$ menit), dalam hal ini yang dipersiapkan penulis adalah sebagai berikut ini.

a Menentukan materi pokok yaitu menulis teks LHO.

b. Menentukan Kompetensi Dasar (KD), Indikator Pencapaian Kompetensi (IPK) serta tujuan pembelajaran mata pelajaran Bahasa Indonesia materi pokok yaitu menulis teks LHO.

c. Membuat Rancangan Pelaksanaan Pembelajaran (RPP) sesuai materi yang akan diajarkan, yaitu materi pokok menulis teks LHO pada mata pelajaran Bahasa Indonesia yang terdiri dari kegiatan awal, kegiatan inti, dan kegiatanakhir.

d. Membuat instrumen penilaian peserta didik yang meliputi penilaian sikap, pengetahuan, dan penilaian kepeterampilan.

e. Menulis lembar penilaian individu.

Siklus II dirancang dengan menggunakan indikator: (a) membenahi kesalahan berbahasa dalam teks LHO, dan (b) menulis teks LHO dengan memperhatikan isi dan aspek kebahasaan. Pertemuan siklus II dirancang untuk melakukan pembelajaran dengan menggunakan model pembelajaran integratif dengan tanya jawab dan diskusi klasikal tentang tentang penulisan teks LHO dan hal-hal yang harus diperhatikan dalam penulisan teks LHO. Kemudian dilanjutkan penugasan individu untuk menulis teks LHO berdasarkan kerangka yang telah dibuat pada pertemuan sebelumnya dengan memperhatikan struktur dan aspek kebahasaan teks LHO. Di akhir kegiatan menulis teks LHO, guru meminta peserta didik untuk kerja berpasangan melakukan koreksi dan perbaikan terhadap teks LHO pasangan masing-masing. Selain itu, guru juga menyiapkan lembar penilaian proses untuk merekam aktivitas dan keaktifan peserta didik selama proses pembelajaran berlangsung

2) Tahap Pelaksanaan

Pelaksanaan proses belajar mengajar untuk siklus II dilaksanakan sebanyak 1 kali pertemuan yang dilaksanakan pada hari Selasa, 7 Agustus 2019 jam pelajaran ke 3-4 pada pukul 8.30 sampai dengan pukul 10.00 WIB. Peneliti memasuki kelas didampingi 1 orang observer dari teman sejawat yang bertindak sebagai pengamat selama penelitian tindakan kelas berlangsung. Alokasi waktu dalam 1 jam pelajaran adalah 45 menit, sehingga total pelaksanaan pembelajaran pada Siklus II adalah $2 \times 45$ menit (90 menit).

Pengamatan dilaksanakan peneliti dan dibantu 1 orang observer, yaitu teman sejawat guru Bahasa Indonesia, SMA Negeri 2 Sungai Raya. Penerapan pendekatan integratif dilaksanakan melalui 5 tahapan yaitu: (a) persiapan, (b) orientasi masalah, (c) penugasan kelompok, (d) presentasi kelompok, dan (e) evaluasi. Pengamatan dilakukan dengan menggunakan instrumen berupa lembar observasi aktivitas guru dan peserta didik untuk merekam kegiatan mereka dalam pembelajaran.

Sebelum memulai pembelajaran guru mengajak peserta didik berdoa sebagai rasa syukur karena mendapat kesempatan mempelajari Teks LHO. Dari sini peserta didik diharapkan termotivasi untuk memiliki semangat dalam mengikuti pembelajaran. Selanjutnya, guru mengawali kegiatan dengan apersepsi, yaitu menanyakan materi yang telah dipelajari pada pertemuan sebelumnya. Selain itu, guru menjelaskan tujuan pembelajaran yang akan dicapai, cakupan materi, dan penjelasan uraian kegiatan pembelajaran.

Hal ini dilakukan agar peserta didik mempunyai kesiapan dalam mengikuti kegiatan pembelajaran yang akan dilakukan. Tahap yang kedua dari proses pembelajaran dengan penerapan pendekatan integratif adalah tahap orientasi masalah. Pada orientasi masalah ini peserta didik diarahkan untuk mengingat kembali materi sebelumnya menggunakan media papan True-False: (a) guru membagikan papan TrueFalse kepada peserta didik, (b) guru menjelaskan bahwa akan ada 10 pernyataan berkaitan dengan materi teks LHO yang telah dipelajari kemudian peserta didik diminta merespon dengan menunjukkan papan B jika jawaban 
benar dan papan S jika jawaban salah, (c) guru menayangkan satu per satu pernyataan dalam tayangan PPT, (d) peserta didik merespon pernyataan melalui papan True-False, (e) guru dan peserta didik membahas ketepatan jawaban. Setelah itu, peserta didik dan guru berdiskusi secara klasikal tentang penulisan teks LHO dan hal-hal yang harus diperhatikan dalam penulisan teks LHO.

Tahapan selanjutnya adalah penugasan individu. Tahapan ini merupakan tahapan paling penting dalam pembelajaran dengan penerapan pendekatan integratif. Kegiatan ini dimulai dengan guru membagikan kerangka teks LHO (pertemuan sebelumnya) dan lembar kerja penulisan teks LHO. Peserta didik mengecek kelengkapan dan ketepatan informasi dalam kerangka teks LHO yang telah dibuat pada pertemuan sebelumnya. Setelah melengkapi informasi dalam kerangka teks LHO, peserta didik menulis teks LHO dalam lembar kerja yang telah dibagikan.

Setelah selesai menulis teks LHO, peserta didik secara berpasangan melakukan koreksi dan perbaikan terhadap teks LHO pasangan masing-masing. Peserta didik melakukan fase editing dengan teknik gesersunting: (a) ketika guru mengatakan "satu", maka peserta didik harus menggeser lembar kerjanya arah kanan, peserta didik yang memegang lembar kerja harus menyunting ketepatan informasi dan kebahasaan dalam pernyataan umum; (b) ketika guru mengatakan "dua", peserta didik harus menggeser lembar kerjanya arah kanan, peserta didik yang memegang lembar kerja harus menyunting ketepatan informasi dan kebahasaan dalam deskripsi bagian; (c) ketika guru mengatakan "tiga", maka peserta didik harus menggeser lembar kerjanya arah kanan, peserta didik yang memegang lembar kerja harus menyunting ketepatan informasi dan kebahasaan dalam deskripsi manfaat. Masing-masing langkah diberi waktu 3-4 menit. Peserta didik diminta memberikan komentar berupa apresiasi, kritik, dan/atau saran dalam kolom yang telah disediakan.

Setelah menyelesaikan tugasnya, peserta didik melakukan tahap selanjutnya yaitu mempersentasikan tugas individu. Peserta didik diminta untuk membacakan teks LHO dan editingnya di depan kelas. Seluruh peserta didik diarahkan untuk menempel teks LHO-nya di mading kelas. Akhir kegiatan dari kegiatan inti adalah peserta didik dan guru melakukan refleksi proses penulisan teks LHO. Peserta didik dan guru menyampaikan hambatan atau kesulitan belajar dan sekaligus mendiskusikan solusinya.

Kegiatan ini dilakukan dengan tujuan untuk mengetahui keberhasilan kegiatan belajarmengajar oleh guru sekaligus mengukur tingkat keberhasilan model pembelajaran integratif dengan penugasan individu yang diterapkan oleh peneliti

\section{3) Hasil Observasi}

Kegiatan pembelajaran Bahasa Indonesia materi menulis teks LHO pada Siklus II dengan mengunakan pendekatan integratif melalui tanya jawab dan diskusi klasikal, yang dilanjutkan penugasan individu untuk menulis teks LHO berdasarkan kerangka yang telah dibuat pada pertemuan sebelumnya, telah memperoleh hasil yang sangat baik karena telah memenuhi kriteria ketuntasan minimal (KKM) klasikal lebih dari 68\%. Rincian persentase nilai tindakan Siklus II adalah sebagai berikut

Tabel 2. Persentase Nilai Tindakan Siklus II

\begin{tabular}{lcc}
\hline \multicolumn{1}{c}{ Ketuntasan Hasil Belajar Peserta didik } & Jumlah & $\begin{array}{c}\text { Persentase } \\
\text { \% }\end{array}$ \\
\hline $\begin{array}{l}\text { Jumlah peserta didik yang tuntas nilai lebih besar sama dengan } \\
\text { 68 }\end{array}$ & 28 & $90 \%$ \\
\hline Jumlah peserta didik yang belum tuntas nilai kurang dari 68 & 3 & $10 \%$ \\
\hline Jumlah peserta didik & 31 & \\
\hline
\end{tabular}


Dari Tabel 1 dan Tabel 2 di atas dapat diketahui bahwa persentase ketuntasan pada Siklus I yang mencapai 38\% mengalami peningkatan pada Siklus II menjadi $90 \%$ dari peserta didik yang berjumlah 21 orang. Peningkatan yang optimal tersebut sangat memuaskan, sehingga peneliti tidak perlu lagi melakukan tindakan dengan siklus berikutnya. Acuan yang digunakan pada penelitian ini adalah kriteria ketuntasan minimal (KKM) klasikal lebih dari 68\%.

\section{4) Refleksi}

Berdasarkan hasil observasi dan analisis pada Siklus II, maka guru bisa menghentikan pemberian tindakan karena hasil yang diperoleh sudah maksimal. Peningkatan peserta didik, baik dalam proses maupun hasil belajar dapat dilihat pada hasil analisis lembar observasi peserta didik dan hasil tes akhir siklus yang peneliti lakukan. Peningkatan tersebut antara lain adalah sebagai berikut.

a. Guru dalam melaksanakan pembelajaran pada Siklus II sudah berpedoman pada hasil refleksi Siklus I, sehingga yang telah direncanakan pada Siklus II dapat terlaksana dengan maksimal.Tingkat keterlaksanaan proses pembelajaran pada Siklus II telah meningkat dibandingkan dengan Siklus I. Hal ini dapat dilihat dari peserta didik yang terlihat cukup aktif dalam penugasan individu.

b. Hasil belajar peserta didik pada Siklus II telah mengalami peningkatan dibandingkan dengan Siklus I, yaitu sebesar $90 \%$. Hal ini telah melewati batas minimal yang ditentukan sekolah yaitu sebesar $68 \%$. Pada siklus II, masih terdapat 3 peserta didik yang belum tuntas dalam belajar. Peserta didik tersebut dikatakan belum tuntas belajar karena mempunyai skor kurang dari 68. Oleh karena itu, peneliti tetap perlu memberikan motivasi kepada seluruh peserta didik agar belajar lebih giat supaya memperoleh hasil yang lebih baik.

Berdasarkan refleksi tersebut, dapat disimpulkan bahwa proses pembelajaran Bahasa Indonesia materi menulis teks LHO dengan pendekatan integratif dan metode penugasan individu dapat meningkatkan hasil belajar peserta didik. Hal ini dapat dilihat dari data yang terdapat pada Tabel 2 di atas bahwa persentase nilai tindakan Siklus II mengalami peningkatan jika dibandingkan dengan data yang terdapat pada Tabel 1

Pembelajaran yang dilakukan di Kelas X IPA2 SMA Negeri 2 Sungai Raya pada pertemuan sebelumnya telah menerapkan pembelajaran yang bersifat konvensional. Peserta didik hanya mendengarkan penjelasan dari guru saja, tanpa melakukan kegiatan pembelajaran yang lebih bermakna untuk mendorong peserta didik terlibat secara aktif di dalam kelas. Fakta di atas bertolak belakang dengan tujuan belajar yang menekankan pada cara-cara belajar yang memberikan berbagai kesempatan kepada peserta didik untuk berinteraksi dan belajar bahasa (Ghazali, 2010).

Berdasarkan permasalahan yang ada, maka peneliti menerapkan pendekatan integratif yang merupakan salah satu strategi pembelajaran yang dapat mengaktifkan semua peserta didik untuk ikut terlibat dalam proses belajar mengajar. Penerapan pendekatan integratif dapat meningkatkan hasil belajar peserta didik pada mata pelajaran Bahasa Indonesia khususnya materi menulis teks LHO. Strategi pembelajaran ini menjadikan peserta didik aktif dalam penugasan individu dan belajar menyampaikan pendapat atau komentar, baik berupa apresiasi, kritik, maupun saran terhadap terhadap teks LHO peserta didik lain. Pelaksanaan tahap dan langkah-langkah kegiatan pembelajaran dengan pendekatan integratif pada Siklus I belum menunjukkan ketuntasan yang optimal dengan persentase ketuntasan 38\%, sehingga dilanjutkan dengan tindakan berikutnya melalui Siklus II. Pada Siklus II pelaksanaan tahap dan langkahlangkah kegiatan pembelajaran mengalami peningkatan ketuntasan hasil belajar yang optimal dengan persentase ketuntasan 90\%, sehingga peneliti menghentikan pemberian tindakan karena hasil yang diperoleh sudah cukup maksimal. Berikut ini daftar nilai hasil belajar peserta didik di setiap siklus 
Tabel 3. Perbandingan Nilai Hasil Belajar Siklus I dan Siklus II

\begin{tabular}{cccc}
\hline No & Nama Peserta Didik & \multicolumn{2}{c}{ Nilai } \\
\cline { 2 - 4 } & Siklus I & Siklus II \\
\hline & Presentase nilai memenuhi KKM & $38 \%$ & $90 \%$ \\
\hline & Presentase nilai kurang dari KKM & $62 \%$ & $10 \%$ \\
\hline
\end{tabular}

Berdasarkan tabel di atas, hasil penelitian yang sudah dilaksanakan pada mata pelajaran Bahasa Indonesia materi menulis teks LHO, dengan menggunakan pendekatan integratif dapat meningkatkan hasil belajar peserta didik. Hasil penelitian tersebut menunjukkan bahwa pada Siklus I terdapat $38 \%$ peserta didik yang mememenuhi KKM meningkat menjadi $90 \%$ pada siklus II, yaitu peserta didik yang memperoleh nilai lebih besar atau sama dengan 68. Hal ini telah melewati batas minimal yang ditentukan sekolah yaitu ketuntasan belajar klasikal sebesar $68 \%$.

Keberhasilan di atas membawa konsekuensi adanya kekurangan dan kelebihan penelitian tindakan kelas dalam pembelajaran Bahasa Indonesia dengan materi menulis teks LHO di kelas X IPA2 SMA Negeri 2 Sungai Raya, yang dilaksanakan pada tanggal 5 hingga 7 Agustus 2019. Kekurangannya adalah sebagai guru, peneliti harus lebih memahami kondisi sosiopsikologis peserta didik yang tentunya membutuhkan waktu yang cukup lama untuk merealisasikannya. Oleh karena itu, peneliti harus lebih cermat dalam mengatur waktu yang sudah direncanakan sebelumnya. Kekurangan yang lain adalah peserta didik akan bosan kalau pendekatan integratif tidak disertai dengan metode yang bervariasi dan media yang menarik bagi peserta didik, maka guru dituntut untuk lebih kreatif inovatif dalam menjalankan pendekatan integratif.

Adapun keunggulan pembelajaran Bahasa Indonesia materi menulis teks LHO dengan pendekatan integratif adalah peserta didik lebih termotivasi dalam belajarnya, karena peserta didik dituntut dapat memahami materi dengan keadaan yang sebenarnya dan dituntut dapat berbicara mengutarakan pendapat tentang teks LHO peserta didik lain. Pendekatan integratif yang dikolaborasikan dengan penugasan individu dapat memberikan stimulan kepada peserta didik untuk memiliki rasa bertanggung jawab terhadap tugasnya

\section{SIMPULAN DAN SARAN Simpulan}

Berdasarkan hasil penelitian dan pembahasan di atas, maka dapat disimpulkan bahwa penerapan pendekatan integratif dalam pembelajaran Bahasa Indonesia dengan materi menulis teks LHO di kelas X IPA2 SMA Negeri 2 Sungai Raya dapat terlaksana dengan baik dan dapat meningkatkan hasil belajar peserta didik. Peningkatan hasil belajar tersebut dapat dilihat dari peningkatan persentase ketuntasan hasil belajar peserta didik, yaitu peserta didik yang memperoleh nilai lebih besar atau sama dengan 68. Peningkatan hasil belajar yang dimaksud adalah dari 38\% pada Siklus I menjadi $90 \%$ pada Siklus II. Implikasi dari peningkatan hasil belajar tersebut adalah pendekatan integratif menuntut guru untuk lebih memahami kondisi sosio-psikologis peserta didik melalui pengaturan waktu yang cermat seperti yang sudah direncanakan sebelumnya.

\section{Saran}

Di samping itu, peningkatan hasil belajar tersebut menuntut guru untuk menggunakan metode yang bervariasi dan media yang menarik bagi peserta didik, agar pembelajaran lebih bermakna, menyenangkan, dan memberi peluang bagi peserta didik untuk terlibat secara aktif dalam pembelajaran. Adapun bagi peserta didik, model pembelajaran integratif menuntut peserta didik untuk belajar melalui keadaan/lingkungan yang sebenarnya, sehingga dari sini peserta didik dapat belajar menyampaikan pendapat atau komentar, baik berupa apresiasi, kritik, maupun saran.

\section{DAFTAR PUSTAKA}


Akbar, \& Sebayang, N. (2015). Penerapan Model Pembelajaran Integratif Untuk Meningkatkan Hasil Belajar Melaksanakan Pekerjaan Dasar-Dasar Survey Dan Pemetaan. Educational Building: Jurnal Pendidikan Teknik Bangunan Dan Sipil, 1(2), 127-132. https://doi.org/10.24114/eb.v1i2.2814

Arikunto, S. dkk. (2008). Penelitian Tindakan Kelas. Jakarta: Bumi Aksara.

Brown, H. D. (2008). Prinsip Pembelajaran dan Pengajaran Bahasa. Diterjemahkan Noor Cholis dan Yusi Avianto Pareanom. Jakarta: KedutaanBesarAmerikaSerikat.

Eggen, P. dan D. K. (2016). Strategi dan Model Pembelajaran: Mengajarkan Konten dan Keterampilan Berpikir. Diterjemahkan Satrio Wahono. Jakarta: PT Indeks.

Ghazali, H. A. S. (2010). Pembelajaran Keterampilan Berbahasa dengan Pendekatan Komunikatif-Interaktif. Bandung: PT Refika Aditama.

Hartinah, S. (2008). Perkembangan Peserta Didik. Bandung: PT Refika Aditama.

Hasanuddin. (2012). Implementasi Pembelajaran RQA Dipadu TPS Melalui Lesson Study
Terhadap Hasil Belajar Mahasiswa. Jurnal Biologi Edukasi, 4(1), 18-29. https://doi. org/10.1017/CBO9781107415324.004

Muhadjir, N. (1987).Ilmu

Pendidikan dan Perubahan Sosial:

Suatu Teori Pendidikan. Yogyakarta:

Reka Sarasih. Mujianto, G., Sunaryo,

H., \& Wurianto, A. B. (2016).

Meningkatkan Kemandirian Belajar

Mahasiswa. JINoP (Jurnal Inovasi

Pembelajaran), 2(November), 360-372.

Muslich, M. (2009). Melaksanakan PTK itu Mudah. Jakarta: Bumi Aksara.

Rahayu, P., Mulyani, S., \& Miswadi, S. S. (2012). Jurnal Pendidikan IPAIndonesia Melalui Lesson Study. Jurnal Pendidikan IPA Indonesia, 1(1),63-70.

Windiatmoko, D. U. (2015). Bahasa Indonesia Dalam Model Pembelajaran Integratif Dan Media Pembelajaran Inovatif Serta Kaitannya Dengan Kecakapan Hidup ( Life Skills ). Seminar Nasional Pendidikan Bahasa Indonesia, 39-45. Solo: Universitas Muhammadiyah Surakarta. 